Euskal ikerketen aldizkaria | Revue d'études basques |

Revista de estudios vascos | Basque studies review

Numéro spécial 3 | 2015

Euskal hizkera eta dialektoak gaur egun

\title{
Egoera predikatu berriak euskaraz
}

\section{Ane Berro}

\section{OpenEdition}

\section{Journals}

Édition électronique

URL : http://journals.openedition.org/lapurdum/2642

DOI : 10.4000/lapurdum.2642

ISSN : 1965-0655

Éditeur

IKER

Édition imprimée

Date de publication : 1 novembre 2015

Pagination : 11-25

ISBN : 9782955341322

ISSN : $1273-3830$

\section{Référence électronique}

Ane Berro, «Egoera predikatu berriak euskaraz », Lapurdum [Linean], Numéro spécial 3 | 2015, Sarean emana----an 12 juillet 2017, kontsultatu 20 avril 2019. URL : http://journals.openedition.org/ lapurdum/2642 ; DOI : 10.4000/lapurdum.2642 


\section{Egoera predikatu berriak euskaraz}

Ane BERRO

Euskal Herriko Unibertsitatea (UPV/EHU)

\section{Laburpena}

Lan honetan, euskarazko aditz batzuen erabilera berriak aztertuko ditut, adibidez, pisatu, neurtu eta usaindurenak, maletak asko pisatzen du bezalako adibideetan. Oro har, erabilera horiek ez dira estandarrean onartzen edo gomendatzen, baina hiztun askorentzat oso arruntak dira. Erabilera horietan, aditzok adiera estatiboa daukatela erakutsiko dut, literaturan erabiltzen diren hainbat test sintaktikoren bitartez. Gainera, eztabaidatuko dut erabilera berri horiek hizkuntz ukipenarekin izan dezaketen zerikusia, euskarazko eta gaztelaniazko pareko formak alderatuz.

\section{Ataria ${ }^{1}$}

Lan honetan, euskarazko aditz batzuen erabilera berriak aztertuko ditut, adibidez, pisatu, neurtu eta usaindurenak. Erakutsiko dudanez, aditz hauek adiera estatiboa izan dezakete zenbait testuingurutan, alboko erdaretan aditz hauen parekoek izaten duten bezala. Erabilera estatibo hauek ez dira, oro har, estandarrean onartzen eta gomendatzen, baina euskal hiztun askorentzat ezagunak dira eta erabili ere erabiltzen dituzte. Lan honetan, aditz sail berri hau arakatuko dut. Lehenik, predikatuak deskribatuko ditut, euren adierari, corpusetako adibideei eta hiztunei galdetutako perpausei begiratuz. Ondoren, aditz hauek benetan estatiboak direla erakutsiko dut, literaturan erabili ohi diren testen bidez. Horrekin batera, aditz hauen

1. Eskerrak eman nahi dizkiet Beatriz Fernandezi, Ane Odriari, Mikel Ayerberi eta nire galdera amaigabeak erantzun dituzten hiztun guztiei. Lanaren erantzukizun osoa nirea da. Emaitza hauetara ekarri gaituen ikerketak Europar Batasunaren ikerketarako, teknologia garatu eta erakusteko Zazpigarren Esparru Programaren laguntza jaso du 613465 diru-laguntza hitzarmenaren bitartez. Gainerakoan, ikerketa lan hau zenbait ikerketa proiekturi esker egin dut: Eusko Jaurlaritzaren BF109.203 doktoretza aurreko beka eta IT665-13 egitasmoa, eta Espainiako Ekonomia eta Lehiakortasun Ministerioaren FFI2014-51878-P egitasmoa. 
ordainetan, euskaraz jatorragoak diren egiturak aurkeztuko ditut eta eztabaidatuko dut erabilera berriek hizkuntza ukipenarekin izan dezaketen zerikusia. Ondorioak laburbilduko ditut lanaren amaieran.

\section{Egoera predikatu berriak}

Euskal hiztun batzuen eguneroko hizketan zenbait egoera predikatu berri antzeman daiteke. Aditz berri hauek batez ere ahozko hizkeran aurkitzen ditugu. Gehienak ez dira estandarrak eta, horren ondorioz, oso gutxi agertzen dira hiztegietan eta idatzizko corpusetan. Nolanahi ere, hiztun batzuentzat (batez ere gazteenentzat) hauetariko batzuk oso naturalak dira. Aipa genitzake, esate baterako, pisatu, neurtu, erre, labaindu/irristatu/lerratu, usaindu, pikatu eta kubritu.

Hauek dira Ereduzko Prosa Gaur (Sarasola, Salaburu, Landa eta Zabaleta, 2011) corpusetik hartutako adibide batzuk:

(1) a. Asko pisatzen du, ez dakit eraman ahal izango duzun (H. Cano 2004: 63)

b. 27 kilometro neurtzen ditu alde zabalean eta 19 kilometro estuan. (Berria, 2004-12-16)

Estatiboak deritzet aditzon erabilera hauei, izan ere, perpaus hauetan predikatuek subjektuaren ezaugarriak adierazten dituzte (pisua, luzera, usaina, tenperatura, zaporea etab.) eta ez subjekturi edo beste partaideren bati jazotzen zaizkien gertaerak. Azken horiei predikatu gertaeradunak esaten zaie.

Predikatu berri horietatik, pisatu eta neurtu dira beharbada gehien normaldu direnak. Pisaturen adiera hori bera Euskaltzaindiaren Hiztegian (EH) (Euskaltzaindia 2012) jasotzen da. Egungo Euskararen Hiztegian (EEH) (Sarasola prestatzen) begiratuz gero ere, pisatu predikatuaren sarrera lexikoan 'pisu jakin bat izan' adiera agertzen da hirugarren zerrendaturik, eta adiera horren barruan, honako adibideak ematen ditu:

(2) Iltzeak ere urrezkoak ziren; bakoitzak kilo erdia pisatzen zuen. (Elizen arteko biblia: 2Kro 3,9)

(3) Barruan harri bat izango balu bezala pisatzen du. (J. Urteaga, 2003: 66)

Neurturen kasuan, adiera estatiboa ez dago horren onartuta. EHko neurturen sarreran, amaierako ohar batean agertzen da Euskaltzaindiak ez duela hobesten soka horrek bost metro neurtzen du/ditu forma, eta aldiz, erabiltzekoa dela soka hori bost metro luze da. Bestetik, EEHk adiera estatiboa jasotzen du bigarren adiera gisa ('luze/zabal/garai izan') eta adibide hauek ematen ditu:

(4) Bi metro neurtzen zuen bufanda. (J. Osoro, 2001: 93)

(5) Phobos [...] forma ez-biribilekoa da eta, gure ilargiarekin konparatuz, adibidez, txiki samarra da: 27 kilometro neurtzen ditu alde zabalean eta 19 kilometro estuan. (Berria, 2004-12-16) 
(6) Eskultura eta arkitekturaren erdibideko panelek 5 x 2,70 zentimetro neurtzen dute, eta bi paretetan daude zintzilik. (Berria, 2004-06-22) Izotz-azazkal 12-15 zentimetro neurtzen dituztenak. (P. Zabala, 2000: 256)

Zerrendatu ditudan beste aditzen artean, usaindu da beharbada gehien erabiltzen direnetariko bat. Neurturekin gertatzen den bezalaxe, usainduren adiera estatiboa ez da jasotzen EHn, baina zerrendaturik dago EEHn ('usaina hedatu').

(8) Istanbuleko emakumeek ere ez dute zuk bezain gozo usaintzen! (F. Juaristi, 2003: 76)

Google-en bilaketa bat eginez gero ere, berehala aurki daitezke adibideak:

(9) Nola usaintzen du zure herriak?

(10) Zer emango didazu aurrena? Ondo usaintzen du... eta bero-beroa dago.

Gainontzeko guztiak ez dira hiztegietan jasotzen. Hiztunei galdetuta, ematen du labaindu/irristatu/lerratu (12) aldaerak direla arraroenak edo gutxien onartzen direnak. Besteak, ordea, ohikoak eta naturalak egiten zaizkie nik galdetutako hiztun gazteei. Hauek dira hiztunei erakutsitako, haiek onartutako, eta batzuetan, haiek proposatutako adibide batzuk:

(11) (Jatetxe batean, zerbitzariak platera ekarri berri dio bezeroari eta esaten dio) Kontuz, ez ukitu. Platerak erretzen du.

(12) (Sukaldeko lanbasa pasa berri du aitak eta seme-alabei esaten die) Kontuz hemendik pasatzean. Lurrak labaintzen du.

(13) Piper hauek asko pikatzen dute.

(14) Lantegi horretako keak oso gaizki usaintzen du.

(15) (Igerileku baten inguruan guraso batek bere seme gaztetxoari esaten dio) Kontuz, ez bota. Kubritu egiten du.

Goian aipatu dudan bezala, aditzon erabilera hauek estatiboak direla deritzot. Hori oso datu adierazgarria da, izan ere, ergatiboz markatutako subjektu bat topatzea itxuraz inergatiboa den predikatu estatibo batean, subjektu ergatiboa semantikoki definitzeko ezaugarri esanguratsu bat da.

\section{Estatibotasuna frogatzen}

Aipatu ditudan aditz gehienek beste adiera gertaeradunak dituzte, eta horiek dira, gainera, corpusetan gehien agertzen direnak eta estandarrean onartuta daudenak. Baten batek pentsa lezake goian erakutsi ditudan adibideak adiera ez-estatibo horien erabilera xelebreak besterik ez direla eta ez dituztela benetan egoera predikatuak islatzen. Atal honetan, zenbait test sintaktikoz baliatuko naiz goian aipatu ditudan aditzak estatiboak direla erakusteko eta hortaz, ezagutu edo sinistu bezalako egoera aditzak direla frogatzeko.

Literaturan, bereziki argumentu egituraz eta gertakari egituraz diharduten lanetan, test 
sintaktiko batzuk erabiltzen dira egoera aditzak eta gertaeradunak bereizteko (ikusi, besteak beste, Vendler 1957/1967, Dowty 1979 eta Fábregas eta Marín 2012). Vendleren 1957/1967 arabera, egoera aditzak (adib. know geography 'geografia jakin' ingelesez) ekintzak (adib. run 'korrika egin') eta burutzapenak (adib. write a letter 'gutun bat idatzi') bezalakoak dira, denboran iraun egiten dutelako (eta hortaz, lorpenetatik bereizten dira, adib. arrive 'heldu'). Alabaina, egoera predikatuak eta orain aipatutako ekintzak eta burutzapenak desberdinak dira egoera predikatuek ez dutelako prozesurik adierazten, hau da, ez dute aditzera ematen garapenik edo faseka antolatutako gertaerarik.

Hemen aztertzen ari garen aditzei begiratuz gero, berehala konturatuko gara euren adiera ez dela prozesu batena. Maletak asko pisatzen du edota mahaiak $1 \mathrm{~m}$ neurtzen $d u$ diogunean, maletak eta mahaiak ez dute inolako garapenik edo prozesurik jasaten. Orobat, platerak erre egiten du eta igerilekuak kubritu egiten $d u$ perpausetan, predikatuak ez du inolako gertaerarik edo prozesurik adierazten, baizik eta subjektuaren ezaugarri bat: platera oso bero dagoela batean eta igerilekua sakona dela bestean. ${ }^{2}$

Esanahiaren aldeak argi ikusten dira gutxieneko bikote hauetan:

(16) a. Etxea erre egin da

b. Zopak erre egiten du

(17) a. Jon labaindu egin da

b. Lurrak labain egiten du

Predikatuen interpretazioa erabat aldatu egiten da $a$ adibidetik $b$ adibidera. A perpausetan, subjektuek trantsizio bat jasaten dute: egoera batetik bestera erre predikatuan, eta posizio batetik bestera labaindu predikatuan. B adibideetan, ordea, ez dago horrelako trantsiziorik: aditzek subjektuaren ezaugarri bat adierazten dute: zopa oso bero dagoela lehenengoan, eta lurra labainkorra dagoela bigarrenean. A adibideetan ikusten denez, subjektuak absolutibo kasua du eta izan da hautatutako aditz laguntzailea; $b$ adibideetan, berriz, subjektuak ergatibo kasua jasotzen du eta *edun aditz laguntzailea hautatzen da. Lehenengoari, konfigurazio inakusatiboa deitzen zaio eta, bigarrenari, inergatiboa. Aditzon bi erabilera horiek bi gertakari egitura desberdinen isla dira: lehenengoak egoera aldaketa aditzak dira, eta bigarrenak, aldiz, egoera aditzak.

Aditz horien bi erabilera horien atzean bi gertakari egitura egoteak azaldu lezake

2. Pisatu eta neurtu literaturan aipatu egiten diren egoera aditzak dira, baina erre, labaindu/irristatu/ lerratu, pikatu eta kubritu ez dira normalean sail horretan aipatzen. Beharbada, Levinen (1993) ingelesezko aditzen sailkapeneko Entitate espezifikoen izateko moduak adierazten dituzten aditzak (ingelesez, Verbs of entity-specific modes of being direlakoen) sailaren barruan sar genitzake. Sail horretako aditzek zenbait entitateren existentzia egoera tipikoak adierazten dituzte eta ondorioz, mota jakin bateko subjektuekin bakarrik agertu ohi dira. 
aditzok zenbait test sintaktikotan duten jokabidea: (i) adiera estatiboa -tzen konfigurazio analitikoan bakarrik ager daiteke eta galdu egiten da -tu konfigurazioan agertuz gero; (ii) -tzen konfigurazioan, irakurketa mugagabea dute (Euskaltzaindia 1987), egoera predikatuek bezala eta gertaeradun predikatuetatik desberdinduz; (iii) astiro-astiro edo apurka-apurka prozesu aditzondoekin bateraezinak dira; (iv) adiera estatiboa galdu egiten dute ari progresiboarekin; (v) ezin dira agertu pertzepzio aditzen osagarri ez-finitu gunean, eta azkenik; (vi) aditz hauekin, apur bat modifikatzaileak gradu irakurketa bakarrik lortzen du eta ez denborazkoa.

Goazen orain test horiek guztiak banan-banan aztertzera.

\subsection{Egoera aditzak eta -tzen konfigurazio analitikoa}

Lan batzuetan erakutsi denez (Euskaltzaindia 1987, Albizu 2001, Alcazar 2002, Berro 2015), euskarazko -tzen konfigurazio analitikoak irakurketa errepikakorra (18) edo mugagabea (19) izan ditzake. Etorri eta halako aditz gertaeradunek errepikakorra izaten dute eta ezagutu moduko egoera aditzek, aldiz, mugagabea. Irakurketa errepikakorrean, gertakaria maiztasunarekin errepikatu egiten dela ulertzen da, adib. "egunero" (18a)-n; irakurketa mugagabean, berriz, predikatuak adierazten duen egoera asertzio denboran indarrean dagoela ulertzen da.
a. Jone Gasteizera busez etortzen da (egunero)
b. Iratik aurreskua dantzatzen du ezkontzetan
a. Jonek Miren ezagutzen du
b. Jonek Jainkoarengan sinisten du

Errepikakorra

Errepikakorra

Mugagabea

Mugagabea

Oro har, egoera predikatuak -tzen konfigurazioan agertu behar dira adiera estatiboa gorde ahal izateko. Izan ere, egoera adierazten duten zenbait aditz, -tu konfigurazioan agertuz gero, inkoatiboak bilakatzen dira (Berro 2015).

(20) Jonek Miren ezagutzen du (egoera) > Jonek Miren ezagutu du (inkoatiboa)

(21) Jonek istorioa sinisten du (egoera) $>$ Jonek istorioa sinistu du (inkoatiboa)

Aztertzen ditugun predikatuek interpretazio mugagabea dute -tzen konfigurazio analitikoan, eta beraz, ezagutu egoera predikatuaren antzekoak dira. Gainera, -tzen formaz ez, ez bada -tu formaz agertzen badira, ez-gramatikalak edo behintzat, oso arraroak, bihurtzen 
dira. $^{3}$

(22) *Zopak erre egin du

(23) ??Maletak asko pisatu du

(24) ??Mahaiak $2 \mathrm{~m}$ neurtu du dutela.

Beraz, badirudi test honetan, bederen, aditz hauek egoera predikatuen eredua jarraitzen

\subsection{Aditzondoak eta modifikatzaileak}

Zenbait ikerketatan, estatibotasuna eta dinamikotasuna bereizteko aditzondoak eta modifikatzaileak erabili izan dira: elementu horiek predikatuarekin batera agertu ote daitezkeen edo ez, edota zein irakurketa izaten duten (Fábregas eta Marín 2012, ikusi baita ere Maienborn 20052007 eta Rothmayr 2009).

Esaterako, Fábregas eta Marínek 2012 erakusten dute egoera predikatuak bateraezinak direla prozesua edo nolabaiteko garapena adierazten duten aditzondoekin, adibidez, astiroastiro eta apurka-apurkarekin. Euskarara etorrita, ikus daiteke aditzondo horiek ezin agertu daitezkeela ezagutu eta sinistu bezalako predikatu estatiboekin (25), ezta lan honetan aztertzen ari garen aditzekin ere (26).

(25) a. Jonek Miren ezagutzen du *astiro-astiro / *apurka-apurka

b. Jonek Jainkoarengan sinisten du *astiro-astiro / *apurka-apurka

(26) a. Maletak asko pisatzen du *astiro-astiro / *apurka-apurka

b. Mahaiak 2 m neurtzen du *astiro-astiro / *apurka-apurka

c. Zopak erre egiten du *astiro-astiro / *apurka-apurka

3. Goiko test hori, beste hizkuntza batzuetan erabiltzen den froga sintaktiko oso ezagun baten parekoa da. Dowtyren arabera (1979: 55-56), ingelesez, egoera predikatuek orainaldi sinplean agertzen direnean, aspektu interpretazio mugagabea izaten dute (Dowtyren hitzetan on-going and non-habitual). Bestalde, predikatu gertaeradunek aspektu irakurketa errepikakorra (habitual) izaten dute.

(i) John knows the answer

Mugagabea

Jon daki det erantzun

'Jonek badaki erantzuna'

(ii) John runs

Errepikakorra

Jon korrika.egin

'Jonek korrika egiten du'

(iii) John builds the house

Errepikakorra

Jon eraiki det etxe

'Jonek etxea eraikitzen du' 
(25a)-ko perpausa gramatikala izan daiteke beste adiera batekin, hots, ezagutuk adiera inkoatiboa duenean, eta beraz, predikatu dinamikoa denean. Predikatu dinamiko prototipikoak direnekin ere, horrelako aditzondoak guztiz naturalak eta gramatikalak dira:

(27) Iratik tangoa dantzatu / dantzatzen du astiro-astiro

(28) Mahaia apurka-apurka apurtu da

Bestalde, (26)-ko perpausak ez-gramatikalak dira, pisatu, neurtu eta erre aditzek, testuinguru horretan behintzat, adiera estatiboa izan behar dutelako nahitaez eta ondorioz, bateraezinak direlako astiro-astiro eta apurka-apurka prozesu aditzondoekin. ${ }^{4}$ Beraz, berriz ere, pisatu eta neurtu moduko aditzak ezaguturen eta sinisturen antzeko jarrera dute eta bereizi egiten dira apurtu eta dantzatu moduko aditzetatik.

Egoera aditzak aztertzen dituzten lanetan aipatu izan den beste test bat apur bat modifikatzailearen interpretazioan datza (Maienborn 2005 2007, Rothmayr 2009, Fábregas eta Marín 2012). Apur batek bi adiera izan ditzake, agertzen den testuinguruaren arabera. Batzuetan, denbora interpretazioa izaten du, hau da, 'denbora tarte txikia' adierazten du. Beste batzuetan, aldiz, gradua edo maila aditzera ematen du, hots, predikatuak adierazten duen ezaugarria edo gertaera zer mailatan edo gradutan dagoen edo gertatu den.
(29) Apur bat hitz egin du
Denbora tarte laburra
(30) Apur bat herdoildu da
Herdoiltasun maila
(31) Mikel apur bat ezagutzen dut
Ezagupen maila

Ekintzak eta egoera aditzak konparatzen baditugu, ekintzetan beti lortu ahal izango dugu apur baten denborazko adiera (32), eta kasu batzuetan, gainera, graduzkoa ere bai. Egoera aditzetan, baina, graduzkoa besterik ezin dugu lortu (33).

(32) a. Apur bat dantzatu du arratsaldean

b. Mirenek korrika egiten du apur bat goizetan Denborazkoa

(33) a. Jonek Miren ezagutzen du apur bat

b. Jonek istorioa sinisten du apur bat Graduzkoa

Pisatu moduko aditzek graduzko irakurketa besterik ezin dute izan:

(34) a. Maletak apur bat pisatzen du

b. Zopak apur bat erretzen du Graduzkoa

c. Igerilekuak apur bat kubritu egiten du

4. Test honen aurrean hiztun batzuek zera diote: erre, pikatu etab. moduko aditzen eduki semantikoa kategorikoki ezeztatu edo baieztatu daiteke (pikatzen dute ala ez dute pikatzen), baina ezin da esanahia moldatu apurka-apurka edo astiro-astiro moduko aditzondoekin. 
Ikus daitekeen moduan, test honetan ere egoera predikatuen jokaera bera dute.

\subsection{Progresiboa eta pertzepzio aditzak}

Literaturan ezaguna da (ikus. adib. Vendler 1957/1967 eta Dowty 1979) egoera predikatuak ez direla, oro har, gramatikalak progresiboarekin batzen ditugunean. ${ }^{5}$

(35) *John is knowing the answer Jon da jakiten det erantzun

'*Jon erantzuna jakiten ari da'

*John is owing me 5 euros' Jon da zor.izaten niri 5 euro.pl

'*Jon 5 euro zor izaten ari da niri'

(37) *John is possessing two houses'

Jon da edukitzen bi etxe.pl

'*Jon bi etxe izaten ari da'

Hemen aztertzen ari garen aditzek ere ez dute onartzen progresiboan jartzerik.

(38) *Maleta asko pisatzen ari da

(39) * Mahaia bi metro neurtzen ari da

(40) \#Platera erretzen ari da

(41) *Igerilekua kubritzen ari da

Gramatikalak izan daitezkeen kasuetan, esate baterako, (40)n, aditzak adiera dinamikoa lortzen du, interpretazio inkoatiboa hain zuzen. Gauza bera gertatzen da estatibo/inkoatibo polisemia duten aditzekin, ezaguturekin adibidez. Progresiboan jarriz gero, irakurketa estatiboa desagertu egiten da.

\section{(42) Jon Mikel ezagutzen ari da}

凶 Egoera / $\square$ Inkoatiboa

Azkenik, pisatu moduko aditzak egoera predikatuekin batera sailkatu behar ditugula erakusten duen beste froga bat da pertzepzio aditzekin duten bateraezinatasuna. Maienbornen (2005) arabera, gertaera aditzak espazio-denborazko entitateak dira, eta ondorioz, hautemangarriak dira, hots, ikus edo entzun daitezke. Hauteman daitezkeenez, pertzepzio aditzen -tzen osagarri ez-finituak izan daitezke:

5. Azken urteetako lan batzuek (Maienborn 2005, Rothmayr 2009, Fábregas eta Marín 2012, Berro 2015) erakutsi dute egoera aditz batzuk progresiboan ager daitezkeela (adib. distiratu, gobernatu, mantendu, eutsi etab.). Aditz horiek sail berezi bat osatzen dute egoera predikatuen barruan: $D$ (avidsoniar)-egoera aditzak. Hemen ez ditut arakatuko, baina interesa duenak goian aipatutako lanetara jo dezake, eta euskararako bereziki Berro (2015) lanera. 
(43) Irati aurreskua dantzatzen ikusi dut

(44) Jon Bilbora etortzen ikusi dut

(45) Mikel hitz egiten entzun dut

Egoera aditzak, ordea, ez dira espazio-denborazko entitateak, hau da, ez dira hautemangarriak. Ondorioz, ezin dute agertu pertzepzio aditzen osagarri ez-finituen gunean. Gune sintaktiko horietan gramatikalak diren kasuetan (46), interpretazio aldaketa bat dago halabeharrez non adiera estatiboa galdu egiten den.

(46) \#Mikel Jon ezagutzen ikusi dut

(47) *Jon istorioa sinisten ikusi/entzun dut

Pisatu moduko aditzekin gauza bera gertatzen da. Interpretazio estatiboa galdu egiten da testuinguru sintaktiko honetan.

(48) *Maleta asko pisatzen ikusi/entzun dut

(49) *Mahaia bi metro neurtzen ikusi/entzun dut

(50) \#Platera erretzen ikusi/entzun dut

(51) *Igerilekua asko kubritzen ikusi dut

Polisemikoak direnek eta adiera gertaeraduna izan dezaketenek automatikoki interpretazio hori lortzen dute (50), eta gainontzekoak ez-gramatikalak dira.

\subsection{Laburbilduz}

Honako taula honetan, aurkeztu ditudan test guztien emaitzak bildu ditut. Ikus daitekeenez, pisatu, neurtu eta abarrek predikatu estatibo "jatorren" jokaera bera dute eta hortaz, predikatu estatiboekin batera sailkatu behar ditugu, gertaeradunetatik bereiziz.

1. taula. Aditzen arteko konparazioa test sintaktikoen bidez.

\begin{tabular}{|l|c|c|c|}
\hline & $\begin{array}{c}\text { Gertaeradunak } \\
\text { (adib. dantzatu })\end{array}$ & $\begin{array}{c}\text { Egoera aditzak } \\
\text { (adib. ezagutu) }\end{array}$ & $\begin{array}{c}\text { Pisatu, } \\
\text { neurtu etab. }\end{array}$ \\
\hline Mugagabea -tzen konfigurazioan & - & + & + \\
\hline Adiera estatiboa galdu -tzen-etik kanpo & + & - & - \\
\hline Prozesu aditzondoekin bateragarriak & + & - & - \\
\hline Denborazko interpretaziorik ez apur batekin & + & - & - \\
\hline Progresiboarekin bateragarriak & + & - & - \\
\hline Pertzepzio aditzekin bateragarriak & + & - & - \\
\hline
\end{tabular}

Atal honekin bukatzeko, literaturan maiz aipatzen den beste diagnostiko bat gogorarazi 
nahi nuke: azpi denbora-tarteko ezaugarria (ingelesez, the subinterval property) (Benett eta Partee 1972). Katz-ek (2003: 218) honela formulatzen du:

(52) Pk azpi denbora-tarteko ezaugarria dauka baldin eta $\mathrm{P}(\mathrm{t})=1$ orduan $\forall \mathrm{t}^{\prime} \subseteq \mathrm{t} \rightarrow \mathrm{P}\left(\mathrm{t}^{\prime}\right)=1$

Formulazioa honela irakurtzen da: Pk azpi denbora-tarteko ezaugarria dauka baldin eta denbora tarte batean $\mathrm{P}$ egia bada, eta denbora-tarte horretako azpi denbora-tarte guztietan P egia bada. Jar dezagun adibide bat. Demagun platera bi minutuz egon dela bero-bero. Bi minutu horietako segundo eta tarte txikiago guztietan, platera bero-bero egon da. Beraz, esan dezakegu "bero-bero egon" predikatuak azpi denbora-tarteko ezaugarria duela. Bestetik, "aurreskua dantzatu" moduko predikatu batek ez du baldintza hori betetzen. Adibidez, demagun Irati 3 minutuz aritu dela aurreskua dantzatzen. Aurreskua bukatu duenean, 3 minutu pasa dira dantzan hasi denetik. Denbora-tarte horretako tarte txikiagoetan ez da egia Iratik aurreskua dantzatu duenik, izan ere, aurreskua dantzatu duela esan ahal izateko, aurreskua bukatu egin behar duelako. Ondorioz, "aurreskua dantzatu" predikatuak ez dauka azpi denbora-tarteko ezaugarria.

Gure aditzetara itzuliz, pisatu, neurtu eta abarrek badute orain deskribatu berri dudan ezaugarria, ezagutu eta sinistu moduko egoera aditzek bezala. Atzo arratsaldean maletak asko pisatzen bazuen, arratsaldeko momentu guztietan eta azpi denbora-tarte guztietan esan genezake maletak asko pisatzen zuela. Predikatu dinamikoek eta gertaeradunek, aldiz, ez dute betetzen baldintza hori, garapen bat adierazten dutelako, eta ondorioz, euren denbora-tarteko zati txiki-txiki bat ezin daitekeelako parekatu euren denbora-tarte osoarekin.

\section{Jatorrizko formak eta ukipena}

Mintzagai ditugun aditzak hizkuntzan dauden beste forma batzuk ordezkatzen hasiak dira. Galdekatu ditugun hiztunek, nahiz eta hemen aipatu ditugun aditz gehien-gehienak onartu eta erabili, beste batzuk ere ezagutzen eta erabiltzen dituzte (eta kasu batzuetan nahiago dituzte). Hauek dira adibide batzuk, mendebaldeko, erdialdeko eta Nafarroa ipar-ekialdeko hiztunei hartutakoak. ${ }^{6}$
a. Minak dira
Pikaturen ordez
b. Erretzen dute
a. Hondo handia dauka
b. Sakon dago
c. Sonda asko dago
d. Badauka kristoren altura
Kubrituren ordez

(54)

6. Hiztunek emandako adibideak estandarrera ekarri ditut, hau da, ez ditut gorde hizkeretako ezaugarri zehatzak, darabilgun eztabaidarako ez baitira garrantzitsuak. 
(55) Kristoren pisua dauka

(56) a. Hiru metro dauzka

b. Hiru metroko luzera dauka

c. Baditu hiru metro

(57)
a. Irristakor dago
Labaindu/irristaturen ordez
b. Labainkor dago
c. Irristatzen zara

Pisaturen ordez

Neurturen ordez

Ikus daitekeenez, forma jator gehienak kopulen bidez eraikitzen dira: eduki, egon, $i z a n . . .3$. ataleko ondoriora berriz joz, egitura kopulatiboen parekide izatea aditz berri hauen estatibotasunaren aldeko beste froga bat da.

Forma berri hauen jatorriari dagokionez, hizkuntza ukipenaren ondorioz sortutakoak izan daitezkeela pentsa genezake. Iritzi horretakoak dira, adibidez, Alberdi eta Sarasola 2001: neurturen erabilera berriak aipatzen dituztenean, gaztelaniak kutsatuak diruditela esaten dute. Goazen orain aztertzera zein erdal formaren ondorioz sortu ahal izan diren lan honetan aztertu ditugun predikatuak. Horretarako, hona ekarriko ditut gorago eman ditudan lau adibide:

(58) a. Etxea erre egin da

b. Zopak erre egiten du

(59) a. Jon labaindu egin da

b. Lurrak labain egiten du

Adibide hauetako a perpausetan, aditza konfigurazio inakusatiboan ageri da: subjektuak absolutibo kasua darama eta aditz laguntzailea izan da. B perpausetan, bestalde, konfigurazio inergatiboa dugu: subjektua ergatiboz markatuta dago eta aditz laguntzailea *edun da. Gorago ere aipatu ditugu batetik bestera dauden bi ezberdintasun hauek (ikus. 2. atala). Esan bezala, forman ez ezik, esanahian ere desberdindu egiten dira aditz pare hauetako bi adibideak: $a$ adibideetakoak, egoera aldaketa predikatuak dira eta $b$ adibideetakoak, berriz, egoera predikatuak. Gaztelaniaz, honako perpausak erabiliko genituzke testuinguru horietan:

(60) a. La casa se ha quemado det etxe se aux erre.part

'Etxea erre da'

b. La sopa quema

det zopa erre

'Zopa bero-bero dago'/Zopak erretzen du'

(61) a. Juan se ha resbalado Jon se aux labaindu.part 'Jon labaindu da'

b. El suelo resbala

det lurra labaindu

'Lurra irristakor dago'/ 'Lurrak irristatzen du'

Quemar eta resbalar polisemikoak dira. Euskarazko erre eta labaindu bezala, egoera 
aldaketa predikatuak edo egoera predikatuak izan daitezke. Gaztelaniaz ez dira bereizten subjektuaren kasuaren edota aditz laguntzailearen bidez zeren gaztelaniaz, subjektu biek kasu bat bera partekatzen baitute eta ez baitute aditz laguntzaile bakar bat baino hautatzen, hots, haber aditza. Edonola ere, beste morfema bat erabiltzen da bereizketa hori egiteko: se klitikoa. Se ezin ager daiteke goiko egoera predikatuekin batera:

(62) \#La sopa se quema

det zopa se erre

\#El suelo se resbala

det lurra se irristatu

Alberdik 2003 dagoeneko aipatu du jatorrizko erdaran se klitikoa egoteak ala ez berebiziko garrantzia duela euskarazko aditz mailegatuetan. Alberdik 2003 euskal aditz mailegatuak arakatu zituen, bereziki arreta jarriz aditz horietako subjektuen kasuan eta aditz laguntzailearen hautaketan. Azterketa horretatik ondorioztatu zuen mailegatutako aditzak era batera edo bestera lerratzeko (konfigurazio inakusatiboan ala inergatiboan) irizpide jakin batzuk daudela, eta ondorioz, ezin daitekeela esan euskal aditz iragangaitzen joera beti ergatibo kasua ezartzea eta *edun aditz laguntzailea aukeratzea denik (cf. Sarasola 1977: 79). Alberdiren arabera, aditz iragangaitzen lerratzean bi aldagaik eragiten dute: (i) aditzen adiera, zehatzago, egiletasuna eta barne-kausalitatea adierazten duten ala ez, eta (ii) jatorrizko erdaran se klitikoa hartzen duten ala ez. Era honetan, abortatu eta bidaiatu moduko maileguzko aditzek ergatibo subjektua eta * $e$ dun aditz laguntzailea hartzen dute, euren adiera egileduna baita. Bestalde, deskuidatu eta mutinatu moduko aditzek absolutibo subjektua eta izan aditz laguntzailea aukeratzen dute, jatorrizko erdaran se klitikoa daramatelako: gaztelaniaz descuidarse eta amotinarse.

Gure predikatuei dagokienez, esan genezake aditza bera kasu gehienetan ez dela mailegatu (dagoeneko euskaraz existitzen baitziren, adib. erre, labaindu, usaindu etab.). Hori gabe, mailegatu dena ez da aditza bera, ez bada aditzaren adiera berria, estatiboa, hain zuzen. Ikusi dugunez, jatorrizko erdaretan adiera horiek ez dute se hartzen (63) (64). Beraz, Alberdik iradoki bezala, badirudi se ez hartzeak nolabaiteko lotura daukala euskaraz aditzok hartzen duten formarekin, izan ere, adiera horiek bateraezinak dira se klitikoarekin eta euskaraz, adiera horietan, ergatibo kasuko subjektua eta * edun aditz laguntzailea aukeratzen dira.

Se klitikoak aditzen gertakari-egituran eta honek sorrarazten duen aspektu interpretazioan duen eragina hainbat lanetan arakatu da (Zubizarreta 1987, Sanz 2000, Cuervo 2003, Folli eta Harley 2004, Basilico 2010). Horietako lan batzuek proposatu dute sek emaitza egoera bat gaineratzen duela (Cuervo 2003, Folli eta Harley 2004). Emaitza egoera gaineratzeak, predikatua egoera-aldaketa bilakatzen du. Beharbada horregatik, erdaraz se daukatenek euskaraz absolutibo subjektua eta izan aditz laguntzailea hartzen dute, egoeraaldaketak adierazten dituzten predikatuak horrela egiten dutelako. Horrek lotura izango luke Aldaik (2009) proposatutakoarekin. Aldairen arabera, mendebaldeko eta erdialdeko euskalkietan absolutibo subjektua hartzen duten aditz iragangaitzak jasailedunak dira, eta, bere ustez, jasailetasuna da, hain zuzen, aditz iragangaitzak era batera edo bestera lerratzea eragiten duen aldagaia. 
Sortu diren predikatu hauek interesgarriak dira ergatibo kasuaren analisiaren ikuspuntutik ere, batez ere bi arrazoirengatik. Batetik, aditz hauek inergatiboak dira: ez dute osagarri zuzenik hartzen eta hala ere, subjektuak ergatiboz markatzen dira. Ondorioz, datu hauek arazotsuak izan daitezke euskarazko ergatibo kasua absolutiboaren ondoren ezartzen dela proposatzen duten teorientzat (Ortiz de Urbina 1989, Bobaljik 1993, Laka 1993, Bittner \& Hale 1996, Fernández 1997 eta Rezac et al. 2014). Bestetik, predikatu hauetan, ergatiboz markatutako subjektua ez da egilea. Hori ere oso adierazgarria da, izan ere, ergatibo kasua berezkotzat daukaten teorietan, normalean ergatibo kasua egiletasunarekin lotu egiten da. Gure aditzetan, ergatibo kasuko subjektua egoeraduna da, aditzak adierazten duen ezaugarriaren jabea. Subjektuak duen rol hori kontuan hartzekoa da ergatibo subjektuen analisia egiten denean.

\section{Ondorioak}

Lan honetan, euskarazko zenbait predikatu estatibo berri arakatu ditut, esate baterako, pisatu, neurtu, usaindu, erre eta kubritu. Gehienak ez dira estandarrean onartzen eta idatzizko testuetan ez dira sarri agertzen. Hala ere, hiztun askorentzat -batez ere gazteenentzat-ezagunak dira eta erabili ere erabiltzen dituzte. Zenbait test sintaktikoren bidez erakutsi dut predikatu hauek estatiboak direla benetan. Ezagutu edo sinistu moduko aditzek bezala jokatzen dute testuinguru hauetan: interpretazio mugagabea dute -tzen konfigurazio analitikoan; adiera estatiboa galtzen dute -tzen konfiguraziotik kanpo; bateraezinak dira nolabaiteko prozesua edo garapena adierazten duten aditzondoekin eta baita progresiboarekin ere; apur bat modifikatzailearekin agertuz gero, honek graduzko interpretazioa izan dezake bakarrik; eta azkenik, ezin dira izan pertzepzio aditzen osagarri ez-finituak.

Predikatu berri horiek euskaraz jatorragoak diren egitura kopulatibo batzuk ordezkatzen hasiak dira, adibidez, pisu handia izan, hiru metro eduki, sakon egon etab. Hiztun batzuek, baita lan batzuek ere (Alberdi eta Salarasola 2001 esaterako), predikatu estatibo hauek hizkuntza ukipenaren ondorioz sortu direla uste dute, zehatzago, gaztelaniaren edo frantsesaren eraginpean. Edozein kasutan, sortu diren aditz berri hauek interesgarriak dira euskarazko aditzen gertakari-egituraren azterketarako, baita ergatibo kasuaren analisirako ere. 


\section{Aipamenak}

Alberdi, X. 2003. Euskal aditz mailegatuen erregimena: hurbilketa', In J.M. Makazaga eta B. Oyharçabal (arg.), P. Lafitteren sortzearen mendemugako biltzarra. Gramatika gaiak. Iker 14 (I). 37-60. Bilbao: Euskaltzaindia.

Alberdi, X. eta I. Sarasola. 2001. Euskal estilo libururantz. Gramatika, estiloa eta hiztegia. Bilbo: EHUko Argitalpen Zerbitzua.

Albizu, P. 2001. Sobre la distribución sintáctica de las formas finitas del verbo vasco: condicionamiento léxico y sintáctico. ASJU 35(1). 65-106.

Alcazar, A. 2002. Aspectual Interpretation in Basque. Ms., University of Southern Califormia, Los Angeles.

Aldai, G. 2009. Euskararen kasu markaketaren aldakortasun dialektala. In B. Fernández, P. Albizu eta R. Etxepare (arg.), Euskara eta euskarak: aldakortasun sintaktikoa aztergai, ASJUren Gehigarriak 52. 5-19. Donostia: UPV/EHU and Gipuzkoako Foru Aldundia.

Bennett, M. eta B. Partee. 1972. Toward the Logic of Tense and Aspect in English. Bloomington: Indiana University Linguistics Club.

Basilico, D.2010. The se Clitic and its Relationship to Paths. Probus 22. 271-302.

Berro, A. 2015. Breaking verbs. From event structure to syntactic categories in Basque. Doktore tesia, UPV/EHU eta Université Bordeaux Montaigne.

Bittner, M. eta K. Hale. 1996. The structural determination of case and agreement. Linguistic Inquiry 27. 1-68.

Bobaljik, J.D. 1993. On Ergativity and Ergative Unergatives. In C.Phillips (arg.), MIT Working Papers in Linguistics 19: Papers on Case and Agreement II. 45-88. Cambridge: MIT.

Cuervo, M.C. Datives at Large. Doktore tesia, MIT.

Dowty, D.R. 1979. Word Meaning and Montague Grammar. The Semantics of Verbs and Times in Generative Semantics and in Montague's PTQ. Dordrecht: D. Reidel Publishing Company.

Euskaltzaindia. 1997[1987]. Euskal Gramatikaren Lehen Urratsak II. Nafarroa: Nafarroako Foru Elkargoa eta Euskaltzaindia.

Euskaltzaindia. 2012. Euskaltzaindiaren Hiztegia. Euskaltzaindia/Elkar/Elhuyar.

Fábregas, A. eta R. Marin. 2012. Differentiating Eventivity from Dynamicity: the Aktionsart of Davidsonian State Verbs. LSRL 42, Southern Utah University. Cedar City, UT.

Fernández, B. 1997. Egiturazko kasuaren erkaketa euskaraz. Doktore tesia, UPV/EHU.

Folli, R. eta H. Harley. 2005. Flavors of v. In P.Kempchinsky \& R.Slabakova (arg.), Aspectual Inquiries. 95-120. Dordrecht: Springer.

Katz, G. 2003. On the Stativity of the English Perfect. In A.Alexiadou, M.Rathert eta A.von Stechow (arg.), Perfect Explorations. 205-234. Berlin/New York: Mouton de Gruyter.

Laka, I. 1993. Unergatives that Assign Ergative, Unaccusatives that Assign Accusative. In 
J.D.Bobaljik \& C.Phillips (arg.), Papers on Case and Agreement I, MITWPL 18. 149172. Cambridge, MA: MITWPL.

Levin, B. 1993. English Verb Classes and Alternations: A Preliminary Investigation. Chicago, Ill.: University of Chicago Press.

Maienborn, C. 2005. On the limits of the Davidsonian approach: The case of copula sentences. Theoretical Linguistics 31 (3). 275-316.

Maienborn, C. 2007. On Davidsonian and Kimian states. In I.Comorovski eta K.von Heusinger (arg.), Existence: syntax and semantics. 107-130. Springer.

Ortiz de Urbina, J. 1989. Parameters in the Grammar of Basque. Studies in Generative Grammar 33. Dordrecht: Foris Publications.

Rezac, M., P. Albizu eta R. Etxepare. 2014. The structural Ergative of Basque and the Theory of Case. Natural Language and Linguistic Theory 32. 1273-1330.

Rothmayr, A. 2009. The Structure of Stative Verbs. Amsterdam/Philadelphia: John Benjamins.

Sanz, M. 2000. Events and predication: A new approach to syntactic processing in English. Amsterdam/Philadelphia: John Benjamins.

Sarasola, I. prestatzen. Egungo Euskararen Hiztegia. Euskara Institutua. UPV/EHU. [http:// www.ehu.eus/en/web/eins/egungo-euskararen-hiztegia-eeh-]

Sarasola, I. 1977. Sobre la bipartición inicial en el análisis en constituyentes, ASJU, XI. 51-90.

Sarasola, I., Salaburu, P., Landa, J. eta J. Zabaleta. 2011. Ereduzko Prosa Gaur. Euskara Institutua. UPV/EHU. [http://www.ehu.eus/en/web/eins/ereduzko-prosa-gaur-epg-]

Vendler, Z. 1957. Verbs and Times. The Philosophical Review, 66-2. 143-160. Reprinted in Vendler 1967.

Vendler, Z. 1967. Linguistics in Philosophy. 97-121. Ithaka, NY: Cornell University Press.

Zubizarreta, M.L. 1987. Levels of representation in the lexicon and in the syntax. Dordercht: Kluwer. 